\title{
Reduction of Botrytis cinerea Infection on Petunia Flowers following Calcium Spray Applications
}

\author{
Katherine Bennett and Jared Jent \\ Department of Plant and Environmental Sciences, Clemson University, \\ E143 Poole Agriculture Center, Clemson, SC 29634
}

\author{
Uttara C. Samarakoon \\ The Ohio State University Agricultural Technical Institute, 1328 \\ Dover Road, Wooster, OH 44691
}

\section{Guido Schnabel and James E. Faust \\ Department of Plant and Environmental Sciences, Clemson University, E143 Poole Agriculture Center, Clemson, SC 29634}

Additional index words. calcium chloride, disease management, electrical conductivity, petunia flower meltdown

\begin{abstract}
Botrytis blight on petunia flowers causes significant losses in the postharvest environment. Infection occurs during greenhouse production, and symptoms are expressed during transport. This phenomenon is termed petunia flower meltdown because of the rapid collapse of flower petal tissue as the plants are transported from the production greenhouse to the retail store. The objective of this study was to determine the effect of calcium (Ca) spray applications on botrytis blight severity in petunia flowers. For the first experiment, petunia 'Pretty Grand Red' plants were sprayed twice per week for 2 weeks with calcium chloride $\left(\mathrm{CaCl}_{2}\right)$ at rates of $0,400,800$, and $1200 \mathrm{mg} \cdot \mathrm{L}^{-1} \mathrm{Ca}$. A fungicide (cyprodinil, 37.5\%; fludioxonil, $25 \%$ ) was used as an additional control treatment. Twenty-four hours after the last treatment, freshly opened flowers were harvested, placed into a humidity chamber with $99 \%$ relative humidity, and inoculated with a Botrytis cinerea spore suspension $\left(1 \times 10^{4}\right.$ conidia/mL). Disease progression was recorded every 12 hours for 72 hours. The results showed a $96 \%$ reduction in botrytis blight severity as $\mathrm{Ca}$ concentration increased from 0 to $1200 \mathrm{mg} \cdot \mathrm{L}^{-1} \mathrm{Ca}$. The Ca treatments provided better disease control than the fungicide treatment because of the fungicide resistance of the isolate used in the study. A second experiment was performed to determine whether the beneficial response to $\mathrm{CaCl}_{2}$ application was influenced by chlorine (CI) or the electrical conductivity (EC) of the spray solutions, and no significant responses were observed. These studies prove $\mathrm{Ca}$ is the sole source of the reduction in botrytis blight severity following treatment with $\mathrm{CaCl}_{2}$ sprays, and demonstrate the benefit of using $\mathrm{Ca}$ as a tool for the management of botrytis blight on petunia flowers.
\end{abstract}

Botrytis cinerea, the causal agent of botrytis blight, is a ubiquitous plant pathogen that infects more than 200 crop species worldwide. Although there are fungicides available

Received for publication 9 May 2019. Accepted for publication 8 Aug. 2019.

Published online 7 January 2020

We thank the American Floral Endowment, the Floriculture Research Alliance, and the U.S. Department of Agriculture-Agricultural Research Service-Floriculture and Nursery Research Initiative for funding this project. We also thank Dr. William Bridges for all his support with statistical analysis, and Patricia Karen Bryson, Kelly Lewis, Suranga Basnagala, and Margaret Williamson for their technical support. Technical contribution no. 6761 of the Clemson University Experiment Station.

J.E.F. is the corresponding author. E-mail: jfaust@ clemson.edu.

This is an open access article distributed under the CC BY-NC-ND license (https://creativecommons. org/licenses/by-nc-nd/4.0/). for botrytis blight management, many chemical classes have low efficacy as a result of the high levels of fungicide resistance in commercial greenhouses (Williamson et al., 2007). Botrytis cinerea becomes a significant threat in greenhouses during periods with relative humidity greater than $93 \%$ (Williamson et al., 2007) and temperatures between 10 and $20^{\circ} \mathrm{C}$; however, infection can also occur at temperatures ranging from $2{ }^{\circ} \mathrm{C}$ to above $25^{\circ} \mathrm{C}$ (Elad and Shtienberg, 1995). Moderate temperatures and/or rainy weather during the spring bedding plant season affect retail sales negatively, which causes growers to hold flowering plants in the greenhouses. During this time, plants grow closer together, forming a denser canopy, and the oldest flowers begin to senesce and die. The senesced flowers then become more susceptible to Botrytis infection as the pathogen favors dying tissue. These conditions increase the amount of inoculum present when the plants are moved into the postharvest environment, resulting in the proliferation of botrytis blight infection on petunia flowers and causing significant losses.

Botrytis cinerea produces cell walldegrading enzymes that play an important role in tissue maceration. Polygalacturonases are the first cell wall-degrading enzymes produced by $B$. cinerea that bind with polygalacturonic acid (pectin material) in the middle lamella in the intercellular spaces of the plant (Cabanne and Donèche, 2002). Calcium may act as a competitive inhibitor for the binding site of pectin material, causing gel formation in the middle lamella as a result of Ca cross-linking in the pectin chains (Conway and Sams, 1984), resulting in polygalacturonic acid becoming less accessible spatially to polygalacturonase enzymes (Cabanne and Donèche, 2002).

Calcium deficiencies are common in horticultural crops (White and Broadley, 2003), and often result from inefficient uptake and distribution of Ca throughout different tissues (Poovaiah, 1988). Calcium uptake is passive via the mass flow of water through the plant and is dependent on transpiration. Flower buds and fruits are low-transpiring organs as a result of their low stomatal density and/or large volume-to-surface area ratio. Similarly, young leaves that are enclosed in heads, such as in head lettuce, have low transpiration rates, making them particularly susceptible to $\mathrm{Ca}$ deficiencies. Reproductive tissues (e.g., fruit and flowers) are mainly supplied with nutrients through the phloem, where transport of $\mathrm{Ca}$ is low (Marschner, 2012). Increasing the $\mathrm{Ca}$ concentration in the nutrient solution can provide sufficient $\mathrm{Ca}$ in leaves that transpire at relatively high rates throughout their life cycle, but not necessarily in lowtranspiring organs (Marschner, 2012).

Numerous studies have examined the effect of $\mathrm{Ca}$ on botrytis blight on horticultural crops. In cut roses, increasing $\mathrm{Ca}$ concentration in the nutrient solutions increased $\mathrm{Ca}$ content of the petals and decreased botrytis blight severity (Baas et al., 2000; Bar-Tal et al., 2001; Volpin and Elad, 1991). Similarly, in potted roses, increasing $\mathrm{Ca}$ in the nutrient solution resulted in greater $\mathrm{Ca}$ in the flower petal tissue and reduced botrytis blight incidence (Starkey and Pedersen, 1997). Two similar studies evaluated preharvest spray applications of calcium sulfate on cut roses that reduced botrytis blight severity in flower petals (De Capdeville et al., 2005; Nabigol, 2012). Bract edge burn disorder of poinsettia begins as necrotic spots along the margin of the bracts, which is caused by a localized $\mathrm{Ca}$ deficiency (Strømme et al., 1994). The necrotic tissue can then be infected with $B$. cinerea, resulting in coalesced lesions that are termed bract edge burn (Barrett et al., 1995). This phenomenon can be reduced with weekly $\mathrm{Ca}$ spray applications during bract development (Woltz and Harbaugh, 1985). Calcium spray applications also increase the strength of the leaves of unrooted cuttings of poinsettia and geranium, and a subsequent reduction in botrytis blight severity was also observed in poinsettia leaves (Samarakoon et al., 2017a). In grapes, preharvest Ca spray 
applications significantly reduced storage rot from B. cinerea (Nigro et al., 2006). Postharvest dips or vacuum infiltration of $\mathrm{Ca}$ on apples increased $\mathrm{Ca}$ content of apples and reduced decay caused by $B$. cinerea (Conway et al., 1993).

Calcium chloride spray solutions provide a means of increasing $\mathrm{Ca}$ content in plant tissues. However, the $\mathrm{CaCl}_{2}$ solutions applied to plants can increase the EC/soluble salts, which have also been shown to suppress various fungal pathogens directly (Deliopoulos et al., 2010), leading to the importance of differentiating between $\mathrm{Ca}$ and $\mathrm{EC}$ effects. In addition, $\mathrm{Cl}$, is also supplied as chloride during $\mathrm{CaCl}_{2}$ applications and may have an effect on Botrytis infection. For example, $300 \mathrm{mg} \cdot \mathrm{L}^{-1} \mathrm{CaCl}_{2}$ and sodium chloride $(\mathrm{NaCl})$ solutions similarly reduced the germination of $B$. cinerea spores (Boumaaza et al., 2015). Studies on B. cinerea, as well as other fungi, have been performed to evaluate the pathogen response to $\mathrm{Cl}$ foliar sprays with varying results. A study on grapes showed that spray applications of potassium chloride $(\mathrm{KCl})$ and $\mathrm{NaCl}$ did not provide any reduction in the development of botrytis blight, whereas the $\mathrm{CaCl}_{2}$ treatment provided significant reduction in botrytis blight development (Nigro et al., 2006). Kettlewell et al. (2000) investigated the use of $\mathrm{KCl}$ sprays for powdery mildew disease (Erysiphe gramminis) of wheat and suggested an osmotic effect on the causal agent for disease reduction.

Based on the literature demonstrating the effect of Ca spray applications on leaf tissue strength and botrytis blight, we hypothesized that Ca may be beneficial for the management of petunia flower meltdown. The objectives of this study were to determine the effect of $\mathrm{CaCl}_{2}$ spray applications on botrytis blight severity on petunia flowers and to determine whether any beneficial response observed was the result of $\mathrm{Ca}, \mathrm{Cl}$, and/or the $\mathrm{EC}$ of the spray solution.

\section{Materials and Methods}

Two experiments were conducted to quantify the effect of $\mathrm{Ca}$ spray applications on the resistance of petunia flowers to botrytis blight. The first experiment examined the response of harvested petunia flowers following spray applications of $\mathrm{CaCl}_{2}$. The second experiment was conducted to determine whether the responses to $\mathrm{CaCl}_{2}$ treatments observed in Expt. 1 were the result of $\mathrm{Ca}, \mathrm{Cl}$, and/or the $\mathrm{EC}$ of the $\mathrm{CaCl}_{2}$ solutions.

Botrytis handling procedures. To obtain a pure culture of a Botrytis isolate, petunia plants were received from a commercial grower, and plant tissue symptomatic of a $B$. cinerea infection was removed, placed in a plastic bag containing a moist paper towel, and incubated on a laboratory bench at $22{ }^{\circ} \mathrm{C}$ until sporulation was observed within 1 to 5 d. A pure culture was obtained by isolating spores from the incubated plant tissue and plating them on a petri dish $(100 \times 15 \mathrm{~mm})$ with potato dextrose agar (PDA) medium (Difco Laboratories, Sparks, MD) under sterile conditions. Mycelia from the first milli- meter of the leading edge of the colony was transferred to new PDA plates. This process was repeated until a pure mycelium culture of a single $B$. cinerea isolate was obtained. Species identification was determined based on spore shape and color, and polymerase chain reaction analysis (Fernández-Ortuño et al., 2011)

For long-term storage, conidia were harvested by pipetting $3 \mathrm{~mL}$ sterile aqueous solution of $0.01 \%$ Tween 80 (Sigma-Aldrich Corporation, St. Louis, MO) and 15\% glycerol onto the petri dish. The spore solution was then transferred to 2-mL cryogenic vials (Nalgene Corporation, Rochester, NY) and stored in an ultralow-temperature freezer at $-80{ }^{\circ} \mathrm{C}$.

To obtain fresh spores for inoculation, the stored spores in cryogenic vials were retrieved from the $-80{ }^{\circ} \mathrm{C}$ freezer and the solution was pipetted onto PDA and allowed to grow for 7 to $10 \mathrm{~d}$. From each incubated PDA plate, mature spores were placed into solution by pipetting $5 \mathrm{~mL}$ sterile deionized water onto the PDA plates and using a sterile stir rod to press lightly on spores to get them to release from the conidiophores and go into solution. The isolate was incubated until sporulation occurred and spores matured from clear to gray over 7 to $10 \mathrm{~d}$. The spore solution was then pipetted from the PDA plate into sterile deionized water to prepare a suspension measured to $1 \times 10^{4}$ conidia $/ \mathrm{mL}$ using a hemocytometer (Bright-line 3110; Hausser Scientific, Horsham, PA) by placing $25 \mu \mathrm{L}$ on each side of the hemocytometer.

General procedures. Petunia plugs were received from a commercial grower (Expt. 1, Petunia $\times$ hybrida 'Pretty Grand Red'; Expt. 2, Petunia $\times$ hybrida 'Dreams Red') and transplanted in 1.4-L round containers containing a peat-based growing medium (Fafard 3B; Conrad Fafard, Inc., Agawam, MA) to provide a supply of flowers for the experiments. The plants were grown in a glass greenhouse at Clemson University, SC (lat. $34.7^{\circ} \mathrm{N}$, long. $82.8^{\circ} \mathrm{W}$ ), with the environment controlled by a climate-control computer (Argus Control Environmental Systems; White Rock, British Columbia, Canada). A constant liquid fertigation program was used, with Peter's Excel Cal-Mag Special (15N$2.2 \mathrm{P}-12.5 \mathrm{~K}-5 \mathrm{Ca}-2 \mathrm{Mg}$; Scotts-Sierra, Marysville, $\mathrm{OH}$ ) providing $150 \mathrm{mg} \cdot \mathrm{L}^{-1} \mathrm{~N}$ and 50 $\mathrm{mg} \cdot \mathrm{L}^{-1} \mathrm{Ca}$ at each irrigation event.

Each experiment had two replications. For Expt. 1, the first replication occurred during October; the second replication occurred during November. The plants were grown with daylength extension lighting with metal halide lamps when solar radiation measured outdoors was less than $200 \mathrm{~W} \cdot \mathrm{m}^{-2}$ from 900 to $2400 \mathrm{HR}$ to promote flowering of this facultative long-day plant during October and November. The daily light integrals in October and November were $16.0 \pm 6.2$ and $11.4 \pm 4.5 \mathrm{~mol} \cdot \mathrm{m}^{-2} \cdot \mathrm{d}^{-1}$, respectively, whereas the average daily temperatures were $22.1 \pm 1.0$ and $21.5 \pm 0.9^{\circ} \mathrm{C}$ in October and November, respectively. For Expt. 2, the first replication took place in June and the second in July. The experiment was conducted under the ambient photoperiod with no supplemental lighting. Plants were shaded with retractable curtains providing $55 \%$ shade when solar radiation measured outside the greenhouse exceeded $800 \mathrm{~W} \cdot \mathrm{m}^{-2}$. The daily light integrals were $18.5 \pm 5.2$ and $15.8 \pm 4.7$ $\mathrm{mol} \cdot \mathrm{m}^{-2} \cdot \mathrm{d}^{-1}$ in June and July, respectively, whereas the average daily temperatures were $24.7 \pm 1.0$ and $25.0 \pm 0.8^{\circ} \mathrm{C}$ in June and July, respectively. For both experiments, all open petunia flowers were removed the day before the final spray application to allow for harvesting of freshly open flowers for the experiment.

Effect of $\mathrm{CaCl}_{2}$ sprays (Expt. 1). Calcium chloride (anhydrous 96\% purity; Thermo Fisher Scientific, Waltham, MA) was dissolved in deionized water to provide 0,400 , 800 , or $1200 \mathrm{mg} \cdot \mathrm{L}^{-1} \mathrm{Ca}$ treatments. Spray applications were made between 1600 and $1700 \mathrm{HR}$ and were applied at a rate of 204 $\mathrm{mL} \cdot \mathrm{m}^{-2}$ using hand sprayers. The $\mathrm{CaCl}_{2}$ applications were made twice per week for 2 weeks. A fungicide control contained two active ingredients, cyprodinil $37.5 \%$ and fludioxonil 25\% (Switch; Syngenta, Greensboro, NC), applied at the recommended rate (449 $\mathrm{mg} \cdot \mathrm{L}^{-1}$ ) for ornamentals. The fungicide spray applications were made twice a week for 2 weeks from 1600 to $1700 \mathrm{HR}$. Five plants per treatment were treated with each of the $\mathrm{Ca}$ rates and the fungicide treatment, whereas 10 plants were treated with deionized water and later were divided into two control groups: noninoculated and inoculated with a conidial suspension. Eighteen flowers were harvested per treatment, and the individual flowers were considered as the individual experimental units.

Separating the effect of $\mathrm{Ca}, \mathrm{Cl}$, and $\mathrm{EC}$ (Expt. 2). Calcium chloride and $\mathrm{KCl}(99 \%$ purity, Thermo Fisher Scientific, Waltham, MA) were mixed in deionized water to provide EC treatments of 3.0 and $6.0 \mathrm{mS} \cdot \mathrm{cm}^{-1}$ for each salt. The $3.0-\mathrm{mS} \cdot \mathrm{cm}^{-1} \mathrm{CaCl}_{2}$ solution provided $800 \mathrm{mg} \cdot \mathrm{L}^{-1} \mathrm{Ca}$ and $1420 \mathrm{mg} \cdot \mathrm{L}^{-1} \mathrm{Cl}$, whereas the $6.0 \mathrm{mS} \cdot \mathrm{cm}^{-1}$ solution provided $1600 \mathrm{mg} \cdot \mathrm{L}^{-1} \mathrm{Ca}$ and $2840 \mathrm{mg} \cdot \mathrm{L}^{-1} \mathrm{Cl}$ (Table 1). The $3.0-\mathrm{mS} \cdot \mathrm{cm}^{-1} \mathrm{KCl}$ solution provided $960 \mathrm{mg} \cdot \mathrm{L}^{-1} \mathrm{~K}$ and $871 \mathrm{mg} \cdot \mathrm{L}^{-1} \mathrm{Cl}$, whereas the $6.0 \mathrm{mS} \cdot \mathrm{cm}^{-1}$ solution provided $1920 \mathrm{mg} \cdot \mathrm{L}^{-1} \mathrm{~K}$ and $1743 \mathrm{mg} \cdot \mathrm{L}^{-1} \mathrm{Cl}$. Two additional $\mathrm{KCl}$ solutions were mixed in deionized water to provide the same $\mathrm{Cl}$ concentrations as delivered in the $\mathrm{CaCl}_{2}$ solutions (e.g., 1420 and $2840 \mathrm{mg} \cdot \mathrm{L}^{-1} \mathrm{Cl}$ ). The ECs of these two $\mathrm{KCl}$ solutions were measured at 4.2 and $8.2 \mathrm{mS} \cdot \mathrm{cm}^{-1}$, respectively. Five plants were treated with each of the $\mathrm{CaCl}_{2}$ and $\mathrm{KCl}$ applications, whereas 10 plants were treated with deionized water and were later divided into two control groups: noninoculated and inoculated with a conidial suspension. Eighteen flowers were harvested per treatment, and the individual flowers were considered as the individual experimental units.

Botrytis inoculation and evaluation. One day after the last treatment spray application, four to five newly open flowers per plant with $3 \mathrm{~cm}$ of pedicel were harvested between 1900 
Table 1. Evaluation of botrytis blight severity on petunia flowers treated with calcium chloride $\left(\mathrm{CaCl}_{2}\right)$ or potassium chloride $(\mathrm{KCl})$ spray applications and then inoculated with a conidial suspension of Botrytis. The $\mathrm{KCl}$ treatments provided equivalent concentrations of chloride $(\mathrm{Cl})$ or electrical conductivity (EC) compared with the $\mathrm{CaCl}_{2}$ treatments. Botrytis blight severity is expressed as a sum of the area under the disease progress curve (AUDPC).

\begin{tabular}{|c|c|c|c|c|c|}
\hline Treatment & $\mathrm{EC}\left(\mathrm{dS} \cdot \mathrm{m}^{-1}\right)$ & $\mathrm{Ca}\left(\mathrm{mg} \cdot \mathrm{L}^{-1}\right)$ & $\mathrm{K}\left(\mathrm{mg} \cdot \mathrm{L}^{-1}\right)$ & $\mathrm{Cl}\left(\mathrm{mg} \cdot \mathrm{L}^{-1}\right)$ & Botrytis blight severity (AUDPC) \\
\hline Control & 0 & 0 & 0 & 0 & $305 \mathrm{a}^{\mathrm{z}}$ \\
\hline & 6.0 & 1,600 & 0 & 2,840 & $73 \mathrm{c}$ \\
\hline \multirow[t]{3}{*}{$\mathrm{KCl}$} & 3.0 & 0 & 960 & 871 & $320 \mathrm{a}$ \\
\hline & 4.2 & 0 & 1,565 & 1,420 & $301 \mathrm{a}$ \\
\hline & 8.2 & 0 & 3,129 & 2,840 & $313 \mathrm{a}$ \\
\hline
\end{tabular}

${ }^{\mathrm{z}}$ Letters indicate significantly different responses using the least significant difference test $(\alpha=0.05)$.

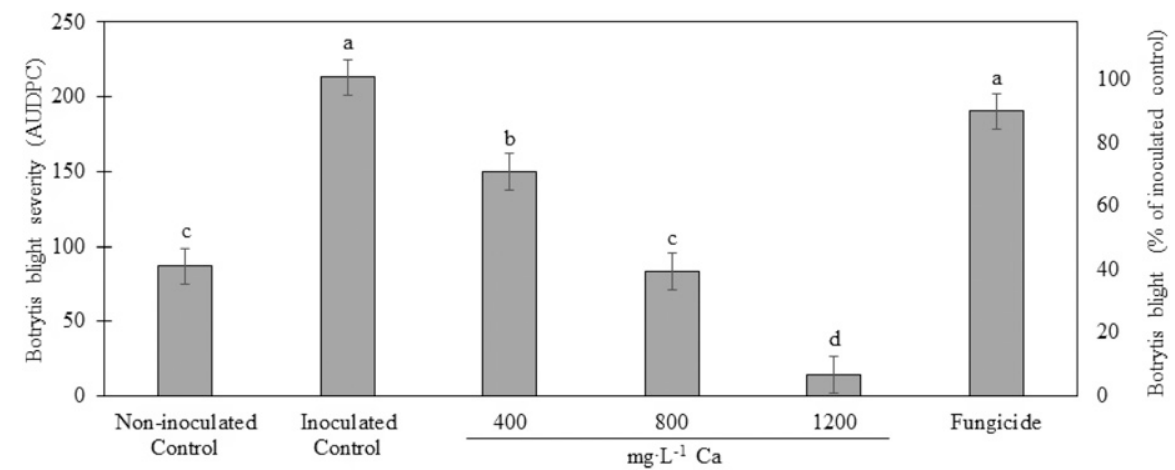

Fig. 1. Evaluation of botrytis blight severity on petunia flowers treated with calcium chloride spray applications or a fungicide (active ingredients: cyprodinil, 37.5\%; fludioxonil, 25\%) and then inoculated with a conidial suspension, with the exception of the uninoculated control group. Botrytis blight severity is expressed as a sum of the area under the disease progress curve (AUDPC). Letters indicate significantly different responses between treatments using the least significant difference test $(\alpha=0.05)$. Error bars represent \pm 1 SE.

to 2000 HR. Flowers were placed immediately in 9 -mL vials filled with $9 \mathrm{~mL}$ deionized water. These flowers were placed into $32.5 \times$ $15.0 \times 17.5$-cm humidity chambers (BioTransport Carrier; Nalgene Corporation, Rochester, NY). Three humidity chambers were used per treatment, with six flowers per chamber. Each chamber contained a piece of polystyrene foam with holes in which the vials were inserted to be held upright. Water $(500 \mathrm{~mL})$ was placed in the bottom of each chamber to provide a high relative humidity $(99.9 \%)$ as measured with a psychrometer (RH300; Extech Instruments, Nashua, NH). Before the chamber lids were sealed, the flowers were inoculated with hand sprayers providing $1 \mathrm{~mL}$ of $1 \times 10^{4}$ inoculum solution per flower and incubated for $72 \mathrm{~h}$ at $22{ }^{\circ} \mathrm{C}$. Disease progression data were collected every $12 \mathrm{~h}$ by taking digital images of the flowers and rating the individual flowers in the images blindly at the end of each experiment. Infection severity was rated on a 1- to 9-point scale based on the area of infected corolla $(1=$ no infection; $9=$ complete necrosis).

Data analysis. Data analysis was performed using JMP Pro version 13.2.0 (SAS Institute Inc., Cary, NC). Analysis of variance (ANOVA) was used to determine treatment effects and Fisher's least significant difference (LSD) test was used to compare means between treatments at $P<0.05$. Treatments were analyzed using the area under the disease progression curve
(AUDPC) to evaluate the total reduction of botrytis blight severity for each treatment compared with the control. To calculate the AUDPC for each treatment, the following equation was used:

$$
\begin{aligned}
\operatorname{AUDPC} & =\sum^{n}\left[t\left(\frac{y-y_{\mathrm{LAG}}}{2}\right)\right] \\
& +\left[t\left(y_{\mathrm{LAG}}-1\right)\right],
\end{aligned}
$$

where $n$ equals the number of time intervals to be summed, $t$ is the time interval between each evaluation (12 h), $y$ is the severity rating, and $y_{\mathrm{LAG}}$ is the previous severity rating time. The AUDPCs at each of the six time intervals are summed to calculate the total area under the curve.

For Expt. 1, the data set consisted of a $2 \times 7$ factorial model evaluating the two replications and seven spray treatments. The magnitude of the AUDPC response differed among the two replications, but the response to the spray treatments was similar within each replication, so data from the two replications were combined. Fisher's LSD test was used to compare means for the factor levels at $P<0.05$. For Expt. 2, the data set consisted of the single factor of spray treatment to evaluate as replications were combined because they were not significantly different. A one-way ANOVA was performed to analyze the effect of spray treatment on reduction of botrytis blight severity. Fisher's LSD test was used to compare means for the factor level at $P<0.05$.

\section{Results}

In Expt. 1, botrytis blight severity decreased as the $\mathrm{Ca}$ concentration supplied in the $\mathrm{CaCl}_{2}$ solution increased from 0 to 1200 $\mathrm{mg} \cdot \mathrm{L}^{-1} \mathrm{Ca}$ (Fig. 1). All three $\mathrm{CaCl}_{2}$ treatments provided better botrytis blight control than the fungicide treatment, which was not different from the inoculated control (i.e., the fungicide had no effect on $B$. cinerea infection). The $800-\mathrm{mg} \cdot \mathrm{L}^{-1} \mathrm{Ca}$ treatment was statistically the same as the noninoculated control, whereas the $1200-\mathrm{mg} \cdot \mathrm{L}^{-1} \mathrm{Ca}$ treatment had a lower botrytis blight severity than the noninoculated control.

In Expt. 2, botrytis blight severity decreased as the $\mathrm{Ca}$ application rate increased (Table 1). The $\mathrm{KCl}$ treatments that provided an equivalent solution $\mathrm{EC}$ or an equivalent concentration of $\mathrm{Cl}$ compared with the $\mathrm{CaCl}_{2}$ treatments showed no significant differences when compared with the inoculated control, nor were there any differences among the replications. Therefore, this experiment indicates $\mathrm{Ca}$ is solely responsible for the reduction in botrytis blight severity.

\section{Discussion}

Two mechanisms are suggested to explain the effectiveness of $\mathrm{Ca}$ to reduce $B$. cinerea infection in horticultural crops. First, $\mathrm{Ca}$ binds with pectic material in the middle lamella to stabilize the cell wall, which makes it more difficult for fungal penetration into the tissue (Conway and Sams, 1984). Tomato fruit sprayed with $\mathrm{Ca}$ resulted in significantly increased levels of membrane and cell wallbound $\mathrm{Ca}$, as well as an increase in free $\mathrm{Ca}$ within the fruit, which also demonstrated a reduction of blossom end rot (SchmitzEiberger et al., 2002). Second, the binding of $\mathrm{Ca}$ to pectin in the middle lamella renders $B$. cinerea incapable of using pectin as a source of carbon, causing a reduction in polygalacturonase activity (Volpin and Elad, 1991). Volpin and Elad (1991) observed complete inhibition of polygalacturonase activity in liquid culture containing $120 \mathrm{mg} \cdot \mathrm{L}^{-1} \mathrm{Ca}$. Nigro et al. (2006) showed that multiple salts reduced polygalacturonase activity, but $\mathrm{CaCl}_{2}$ demonstrated the greatest efficacy.

Botrytis cinerea exhibits incredible genetic plasticity, which allows for fungicide resistance to occur rapidly when under selection pressure from fungicide applications (Williamson et al., 2007). The results presented in this manuscript 
showed inadequate control of $B$. cinerea from the fungicide treatment. Further testing of this isolate, which was recovered from a shipment of petunia plants received from a commercial grower, resulted in the discovery of the first isolate from greenhouse-grown ornamentals displaying resistance to six chemical classes of fungicides commonly used for botrytis blight management (Samarakoon et al., 2017b). Ca sprays are useful for managing botrytis blight, especially when dealing with fungicide-resistant isolates.

In conclusion, the results from this study clearly demonstrate $\mathrm{Ca}$ is the factor influencing the reduction in botrytis blight severity. Increasing the $\mathrm{Ca}$ concentration in the spray solution provides decreased botrytis blight severity up to $1200 \mathrm{mg} \cdot \mathrm{L}^{-1}$. This study demonstrates the potential usefulness of implementing $\mathrm{Ca}$ sprays during greenhouse production to reduce botrytis blight during shipping. Calcium spray applications provide another management strategy for growers to use in addition to conventional fungicides or as option to reduce the number of fungicide applications and thus reduce the selection pressure for fungicide resistance.

\section{Literature Cited}

Baas, R., N. Marissen, and A. Dik. 2000. Cut rose quality as affected by calcium supply and translocation. Acta Hort. 518:45-54.

Barrett, J.E., T.A. Nell, T.J. Blom, and P.A. Hammer. 1995. Poinsettia bract edge burn: Potential causes and role of calcium sprays and Botrytis. HortScience 30:771.

Bar-Tal, A., R. Baas, R. Ganmore-Neumann, A. Dik, N. Marissen, A. Silber, S. Davidov, A. Hazan, B. Kirshner, and Y. Elad. 2001. Rose flower production and quality as affected by $\mathrm{Ca}$ concentration in the petal. Agronomie 21:393-402.

Boumaaza, B., M. Benkhelifa, and M. Belkhoudja. 2015. Effects of two salts compounds on mycelial growth, sporulation, and spore germination of six isolates of Botrytis cinerea in the western North of Algeria. Intl. J. Microbiol. 2015:1-8.

Cabanne, C. and B. Donèche. 2002. Purification and characterization of two isozymes of polygalacturonase from Botrytis cinerea. Effect of calcium ions on polygalacturonase activity. Microbiol. Res. 157:183-189.

Conway, W.S. and C.E. Sams. 1984. Possible mechanisms by which postharvest calcium treatment reduces decay in apples. Phytopathology 74:208-210.

Conway, W.S., R.B. Tobias, and D. Sams. 1993. Reduction of storage decay in apples by postharvest calcium infiltration. Acta Hort. 326: $115-122$.

De Capdeville, G., L.A. Maffia, F.L. Finger, and U.G. Batista. 2005. Pre-harvest calcium sulfate applications affect vase life and severity of gray mold in cut roses. Scientia Hort. 103:329-338.

Deliopoulos, T., P.S. Kettlewell, and M.C. Hare. 2010. Fungal disease suppression by inorganic salts: A review. Crop Prot. 29:1059-1075.

Elad, Y. and D. Shtienberg. 1995. Botrytis cinerea in greenhouse vegetables: Chemical, cultural, physiological and biological controls and their integration. Integrated Pest Mgt. Rev. 1:15-29.

Fernández-Ortuño, D., X. Li, W. Chai, and G. Schnabel. 2011. First report of gray mold of strawberry caused by Botrytis cinerea in South Carolina. Plant Dis. 95:1482.

Kettlewell, P.S., J.W. Cook, and D.W. Parry. 2000. Evidence for an osmotic mechanism in the control of powdery mildew disease of wheat by foliar-applied potassium chloride. Eur. J. Plant Pathol. 106:297-300.

Marschner, P. 2012. Marschner's mineral nutrition of higher plants. Vol. 89. 3rd ed. Academic Press, Waltham, MA.

Nabigol, A. 2012. Pre-harvest calcium sulfate application improves postharvest quality of cut rose flowers. Afr. J. Biotechnol. 11:10781083.

Nigro, F., L. Schena, A. Ligorio, I. Pentimone, A. Ippolito, and M.G. Salerno. 2006. Control of table grape storage rots by pre-harvest applications of salts. Postharvest Biol. Technol. 42:142-149.

Poovaiah, B.W. 1988. Calcium and senescence, p. 369-389. In: L.D. Nooden and A.C. Leopold (eds.). Senescence and aging in plants. Academic Press, San Diego, CA.

Samarakoon, U.C., J.E. Faust, and J.M. Dole. 2017a. Quantifying the effects of foliarapplied calcium chloride and its contribution to postharvest durability of unrooted cuttings. HortScience 52:1790-1795.

Samarakoon, U.C., G. Schnabel, J.E. Faust, K. Bennett, J. Jent, M.J. Hu, S. Basnagala, and M. Williamson. 2017b. First report of resistance to multiple chemical classes of fungicides in Botrytis cinerea, the causal agent of gray mold from greenhouse-grown petunia in Florida. Plant Dis. 101:1052.

Schmitz-Eiberger, M., R. Haefs, and G. Noga. 2002. Calcium deficiency-influence on the antioxidative defense system in tomato plants. J. Plant Physiol. 159:733.

Starkey, K.R. and A.R. Pedersen. 1997. Increased levels of calcium in the nutrient solution improves the postharvest life of potted roses. J. Amer. Soc. Hort. Sci. 122:863-868.

Strømme, E., A.R. Selmer-Olsen, H.R. Gislerød, and R. Moe. 1994. Cultivar differences in nutrient absorption and susceptibility to bract necrosis in poinsettia (Euphorbia pulcherrima Willd. ex Klotzsch). Gartenbauwissenschaft 59:6-12.

Volpin, H. and Y. Elad. 1991. Influence of calcium nutrition on susceptibility of rose flowers to botrytis blight. Phytopathology 81:1390-1394.

White, P.J. and M.R. Broadley. 2003. Calcium in plants. Ann. Bot. 92:487-511.

Williamson, B., B. Tudzynski, P. Tudzynski, and J.A. van Kan. 2007. Botrytis cinerea: The cause of grey mould disease. Mol. Plant Pathol. 8:561-580.

Woltz, S.S. and B.K. Harbaugh. 1985. Effect of nutritional balance on bract and foliar necroses of poinsettia. Plant Dis. 66:218-220. 